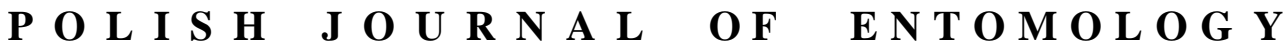

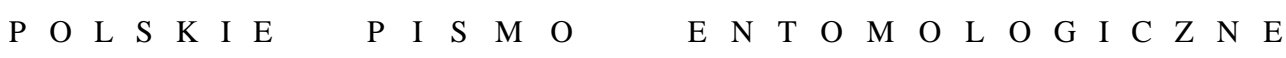

VOL. 85: 105-119

Lublin

30 March 2016

DOI: $10.1515 /$ pjen-2016-0005

\section{Systematics and faunistics of Neotropical Grapholitini, 3: Satronia HEINRICH, 1926 (Lepidoptera: Tortricidae)}

\author{
JÓZEF RAZOWSKI $^{1 *}$, VITOR OSMAR BECKER $^{2}$ \\ ${ }^{1}$ Institute of Systematic and Evolution of Animals, Polish Academy of Sciences, Kraków, \\ 31-016 Sławkowska 17, Poland \\ ${ }^{2}$ Reserve Serra Bonita, P.O. Box 01, 45880 Camacan BA, Brazil
}

\begin{abstract}
The genus Satronia is redescribed and discussed. Distributional data on 11 species are given; 9 new species (Satronia pentha sp. n., S. priva sp. n., S. catharma sp. n., S. sesops sp. n., $S$. mantissa sp. n., S. lita sp. n., S. laepha sp. n., S. sinuata sp. n., S. pheidologeton sp. n.) are described, and references to papers on Neotropical Grapholitini are provided.
\end{abstract}

KEY WORDS: Lepidoptera, Tortricidae, Grapholitini, Satronia, new species, distribution, Neotropics.

\section{INTRODUCTION}

Grapholitini are rather well represented in the Neotropics. POWELL et al. (1995) listed 123 species and 10 genera. Recently RAZOWSKI (2013a) described two genera (Ranapoaca, Phloerampha) and 42 species, and some smaller papers concerning particular genera were published:

- RAZOWSKI \& BECKER (2011) - Ricula HEINRICH, 1926, Talponia HEINRICH, 1926, Riculomorpha ROTA \& BROWN, 2009;

- RAZOWSKI \& BECKER (2012a) - Ethelgoda HEINRICH, 1926, Ofatulena HEINRICH, 1926, Cyanocydia RAZOWSKI \& BECKER, 2012, Metacydia RAZOWSKI \& BECKER, 2012;

- RAZOWSKI \& BECKER (2012b) - Dichrorampha GUENÉE, 1845;

- RAZOWSKI \& BECKER (2013a) - Phloerampha RAZOWsKI, 2011, Goditha HEINRICH, 1926,

*Corresponding author: Razowski@isez.pan.krakow.pl 
Ranapoaca RAZOWSKI, 2011;

- RAZOWSKI \& BECKER (2013b) - Grapholita TREITSCHKE, 1929 Eriosocia RAzOWSKI \& BROWN, 2008, Coniostola DiAKONOFF, 1961;

- RAZOWSKI \& BECKER (2014) - Cydia HÜBNER, 1825;

- RAZOWSKI \& BROWN (2008): Eriosocia RAZOWSKI \& BROWN, 2008.

ADAMSKI \& BROWN (2001) revised the Ecdytolopha group of genera (Ecdytolopha ZELLER, 1875, Gymnandrosoma DYAR, 1904, Pseudogalleria RAGONOT, 1884) and BROWN \& BAIXERAS (2006) described Macrocydia. Descriptions of some grapholitine species are scattered about the recent literature.

All the specimens were collected by the junior author; the material examined, including the holotypes of the newly described species, is preserved in the BECKER Collection, Camacan, and will be deposited in one of the Brazilian Museums in the future. Some spare specimens have been kindly donated to the Institute of Systematics and Evolution of Animals, PAS, Kraków.

Note. The numbers cited on the labels of the type material are the entry numbers of the specimens in the register book of the BECKER Collection. Abbreviations: BC - BECKER Collection, GS - genitalia slide; WZ - W. ZAJDA.

\section{Acknowledgements}

The authors thank Mr A. CZEKAJ, Kraków for taking the photographs and arranging the plates.

\section{SYSTEMATICS}

\section{Satronia HEINRICH, 1926}

Satronia HEINRICH, 1926, Bull. U.S. Natn. Mus., 132: 17; type-species: Satronia tantilla HEINRICH, 1926 (Florida, U.S.A.). BROWN, 2005, Tortricidae (Lepidoptera) [in] World Catalogue of Insects, 5: 547.

Satronia had been established and regarded as a monotypic genus until RAZOWSKI (2011) included two new species in it. Currently twelve species are known.

HEINRICH (1926) described the venation and realized the hindwing pecten was lacking. He wrote that in the male genitalia the uncus and socii are absent and "abdomen of male with lateral hair tufts from sternite of eighth segment". The female remained unknown. HEINRICH stated that Satronia is "a higher development from Ricula, the male genitalia are similar in both except for the socii". He correctly surmised that Satronia is probably of tropical origin. 
Based on the material examined we found that Satronia is characterized by a slender forewing, usually simple markings and the lack of a terminal row of dots on the forewing. There are usually some strigulae and dots in the subterminal fascia, and the costal half of the median fascia is well developed, often extending near the middle of the median cell posteriorly.

The male genitalia have an uncus-like apical lobe or prominence marked by long (usually two) ventro-terminal setae, which probably represent a remnant of the socii; the valva is variable in shape, usually similar to that of Ricula HEINRICH, 1926.

The female genitalia (known only in S. sesops and S. priva) have a broad, plate-shaped sterigma and a large membranous area of the ostium bursae in the latter protected by a median sclerite; the sclerite of the antrum and the median part of the ductus bursae are rather weak; the ductus seminalis originates in the median part of the latter from the sclerite, which we can treat as the cingulum; only one signum is present in the corpus bursae.

The biology is unknown except for the altitudes at which the adults were collected: 5-1100 $\mathrm{m}$.

Distribution. This genus is distributed from Florida, U.S.A. to Brazil (Federal District, Goias, Minas Gerais, Alagoas, Santa Catarina); it is also known from Costa Rica.

\section{Satronia pentha sp. $\mathbf{n}$.}

(Figs 1, 14)

\section{Diagnosis}

S. pentha is similar to Sereda tantilla HEINRICH, 1926 from Florida, U.S.A. but differs from it in its large, tapering terminad process of the tegumen and short cucullus.

\section{Description}

Wingspan $11 \mathrm{~mm}$. Head and thorax grey, labial palpus brown-grey terminally. Forewing slender, expanding slightly terminally; costa almost straight; termen somewhat oblique. Ground colour grey with indistinct brown hue; transverse, convex lines browner; costal strigulae grey, divisions brown; three elongate strigulae along termen. Markings brown consisting of costal half of median fascia, broadening extending posteriorly to the end of median cell; apex of wing concolorous. Cilia brownish. Hindwing pale brown; cilia paler.

Male genitalia (Fig. 1). Terminal lobe of tegumen large, tapering apically; basal half of valva broad; neck slender; sacculus angulate, rounded; cucullus shorter than the latter; aedeagus moderate.

Female unknown. 


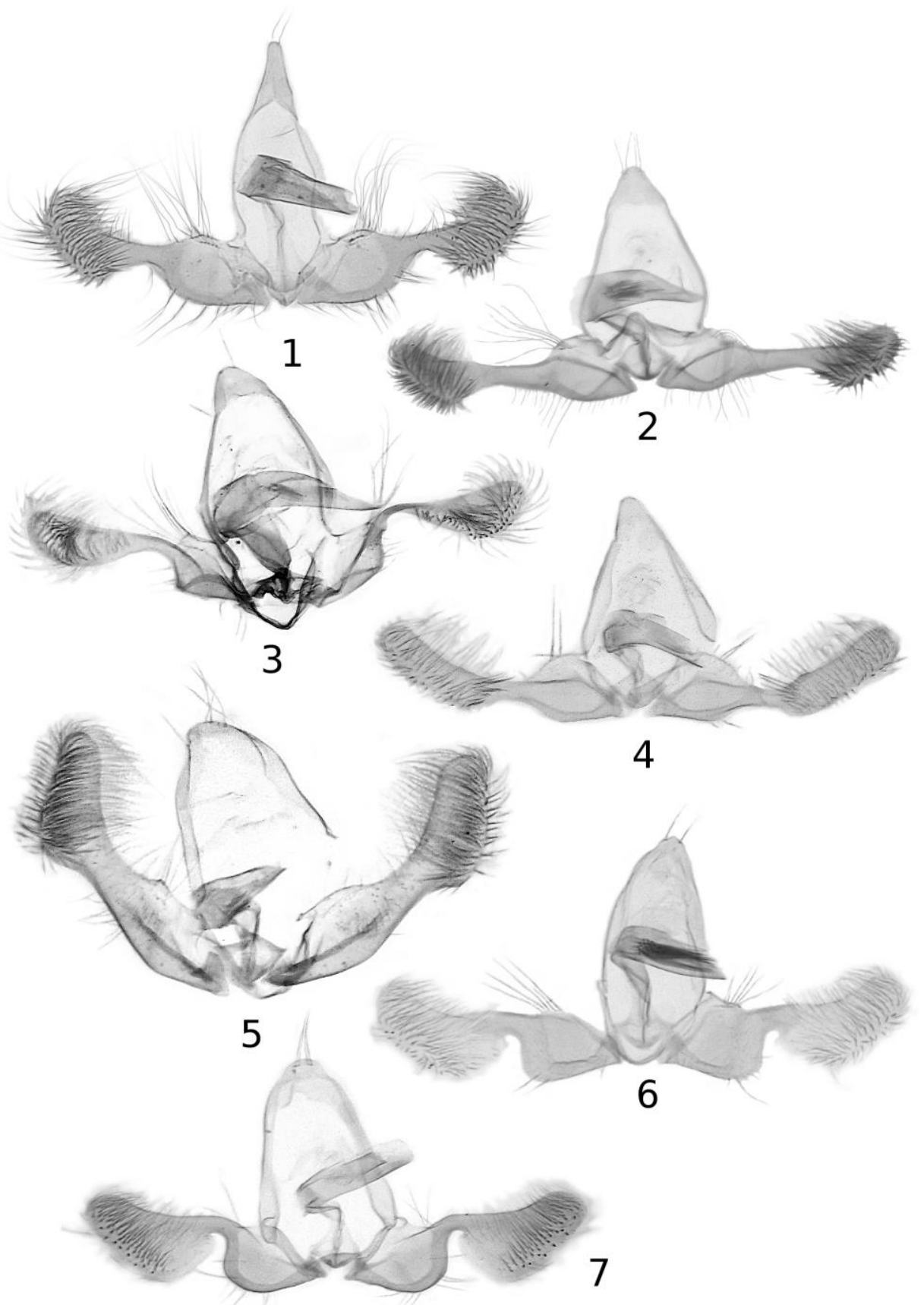

Figs 1-7. Male genitalia of Satronia HEINRICH, 1926: $1-S$. pentha sp. n., holotype, 2 - S. selvae sp. n., holotype, 3 - S. priva sp. n., holotype, 4 - S. catharma sp. n., holotype, 5 -S. sesops sp. n., holotype, 6 - S. mantissa sp. n., holotype, $7-S$. mesaea sp. n., holotype. 


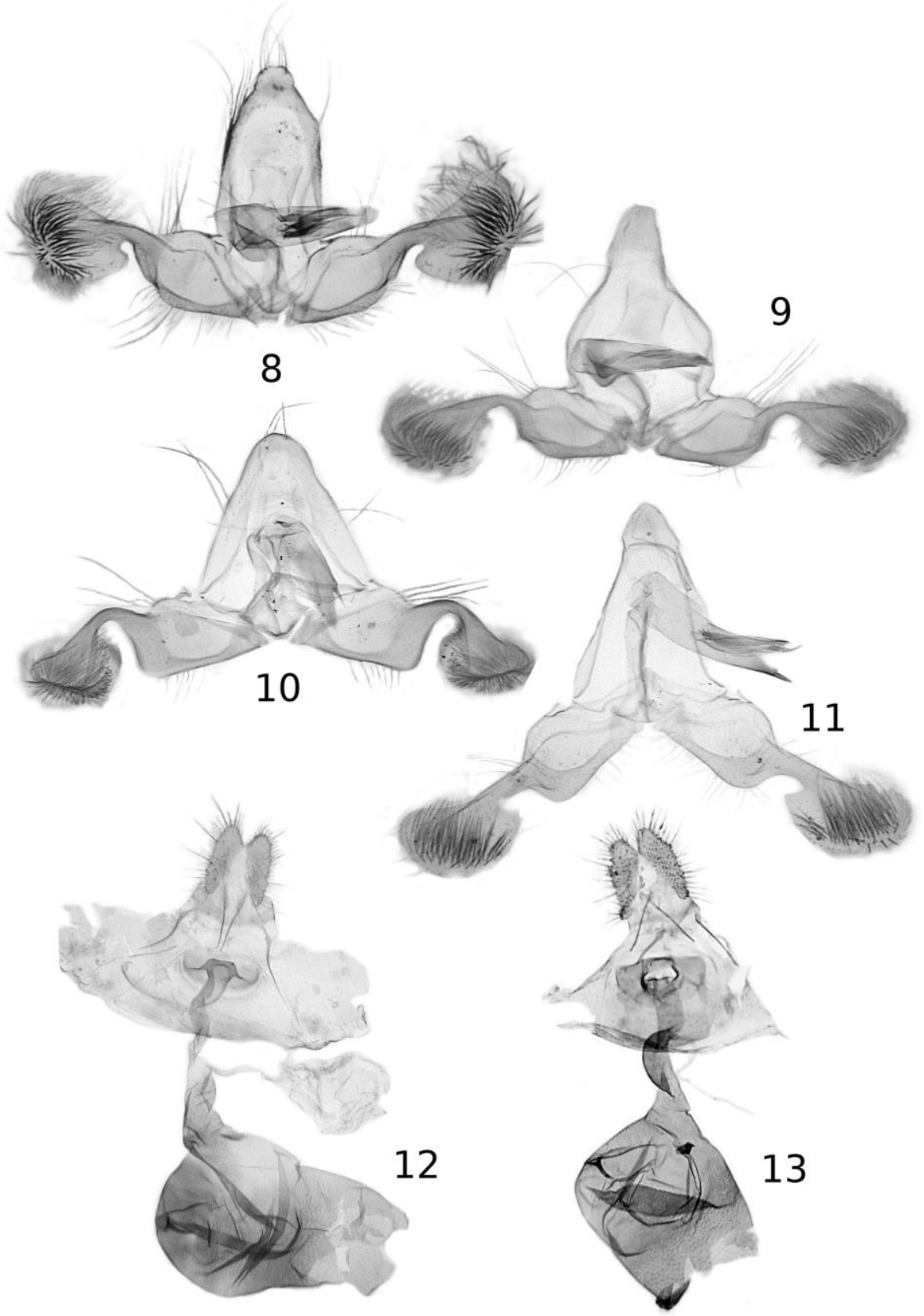

Figs 8-13. Male and female genitalia of Satronia HEINRICH, 1926: 8 - S. lita sp. n., holotype, $9-$ S. laepha sp. n., holotype, $10-S$. sinuata sp. n., holotype, $11-S$. pheidologeton $\mathrm{sp} . \mathrm{n}$., holotype, $S$. priva sp. n., paratype, $13-S$. sesops sp. n., paratype. 

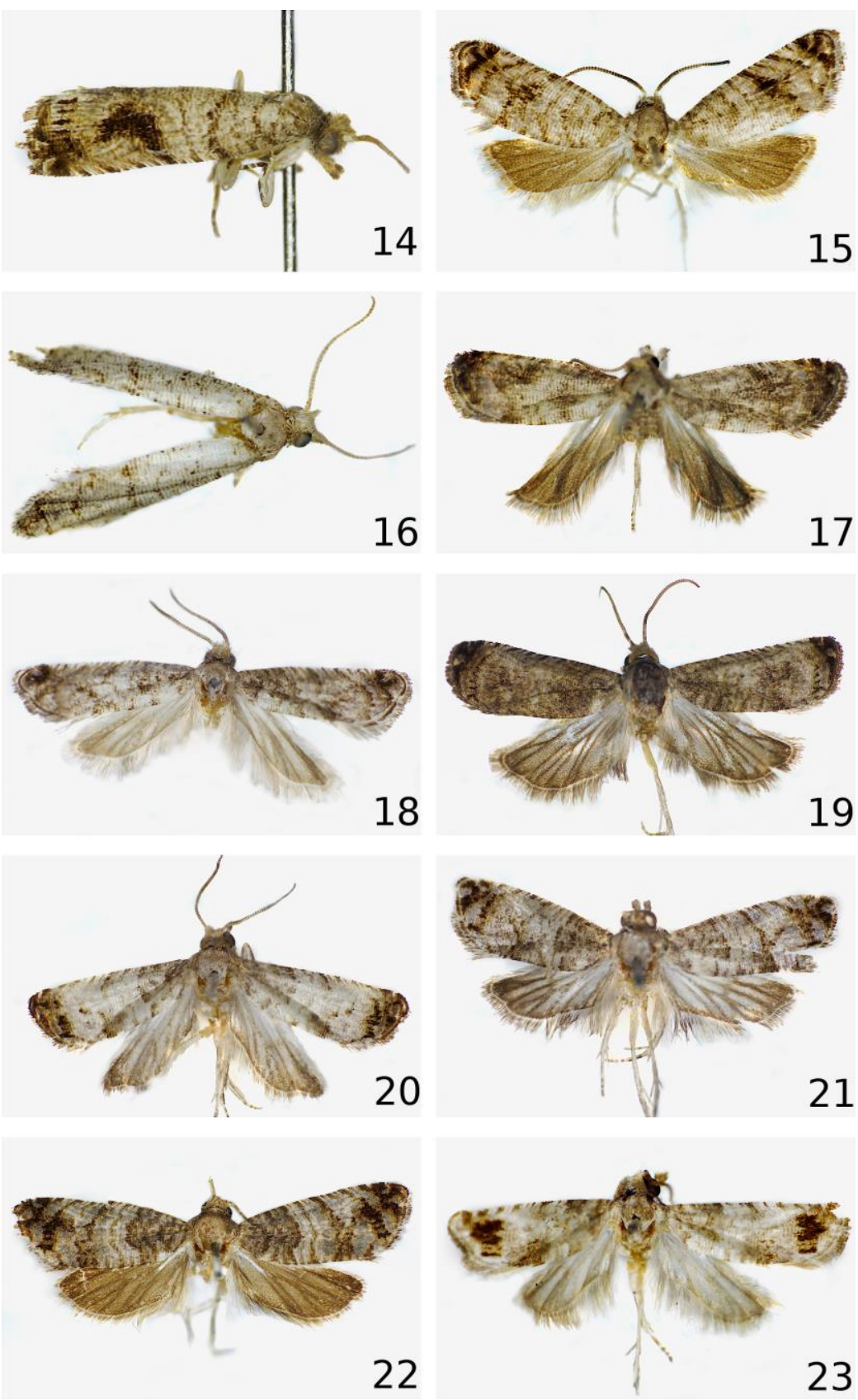

Figs 14-23. Adults of Satronia HEINRICH, 1926: 14 - S. pentha sp. n., holotype, $15-S$. priva sp. n., holotype, $16-S$. catharma sp. n., holotype, $17-S$. sesops sp. n., paratype, $18-S$. mantissa sp. n., holotype, $19-S$. mesaea sp. n., holotype, $20-S$. lita sp. n., holotype, $21-S$. laepha sp. n., holotype, 22 - S. sinuata sp. n., holotype, 23 - S. pheidologeton sp. n., holotype. 


\section{Material examined}

Holotype male: "Costa Rica: Turrialba 600 m, IX. 1971, V.O. BECKER Col; Col. BECKER 35479”; GS 973 WZ.

\section{Etymology}

The specific epithet refers to the colouration of the moth; Greek: penthos - sorrowful.

\section{Satronia selvae RAZOWSKI, 2011}

\section{Material examined}

Three males from Costa Rica (Turrialba 600 m, II. 1972, BC 36172; VI. 1972, BC 36725; IX. 1971, BC 35497; GS 988 WZ, 989 WZ, 991 WZ).

\section{Remarks}

S. selvae was described from the Province of Heredia, Costa Rica from one male.

We also examined one specimen from Brazil, which is most probably conspecific (Teresina, Goias 500 m, 29. V. 1992, BC 92641, GS 885 WZ), but differs slightly from the Costa Rican specimens in the male genitalia (Fig. 2) and facies.

\section{Satronia priva sp. $\mathbf{n}$.}

(Figs 3, 15)

\section{Diagnosis}

Facies as in $S$. selvae but with a grey spot beneath the forewing apex; the valva has a long neck, and the proximal part of the cucullus is subtriangular.

\section{Description}

Wingspan $8 \mathrm{~mm}$ (in one paratype ca. $9 \mathrm{~mm}$ ). Head and thorax grey; forewing as in the preceding species. Ground colour grey; costal strigulae small; divisions brown-grey; no terminal dots. Seven brownish lines from base of wing to before apex separated by subapical fascia; median fascia typical of the genus, weak, brownish towards dorsum. Cilia darker than ground colour. Hindwing brownish; cilia much paler.

Male genitalia (Fig. 3). Top of tegumen short; valva broad basally; neck slender extending towards cucullus; sacculus convex, angulate; cucullus subtriangular, elongate proximally; aedeagus large, tapering and extending ventro-terminally. 
Female genitalia (Fig. 12). Sterigma transversely oval, almost straight posteriorly; large, well sclerotized lobe protecting ostium bursae; sclerite of antrum weak; one signum present.

\section{Material examined}

Holotype male: "Brasil: D[istrito]F[ederal], 16. X. 1990, V.O. BECKER Col; Col. BECKER 969336"; GS 406. Paratypes one male and one female from same locality dated 27. V. 1980, Colln Nr. 58275; GS 880 WZ.

\section{Etymology}

The name refers to the systematic position of the moth; Latin: priva - singular.

\section{Satronia catharma sp. $\mathbf{n}$.}

(Figs 4, 16)

\section{Diagnosis}

Similar to $S$. selvae but $S$. catharma has a long cucullus, a slenderer aedeagus; the forewing has a pale colouration, and the median fascia is atrophied.

\section{Description}

Wingspan $10 \mathrm{~mm}$. Head and thorax whitish grey. Forewing slender. Ground colour whitish grey; costal strigulae hardly visible, divisions slender, numerous, pale brown; no terminal dots. Traces of transverse lines in basal half of wing; median fascia reduced to brownish, slightly convex line; subterminal line more bent; terminal line straight, short; apex rather concolorous with ground colour. Cilia whitish brown. Hindwing pale brownish grey; cilia paler.

Male genitalia (Fig. 4). Terminal lobe of tegumen broad; valva broad basally; neck short, slender; cucullus very long, slender; aedeagus slender.

Female unknown.

\section{Material examined}

Holotype male: "Brasil: M[inas]G[erais], Nova Lima 850 m, 30. XII. 1988, V.O. BECKER Col; Col. BECKER 60566”; GS 871 WZ.

\section{Etymology}

The name refers to the colouration of wings; Greek: katharma - dirt. 


\section{Satronia sesops sp. $\mathbf{n}$.}

(Figs 5, 13, 17)

\section{Diagnosis}

Similar to $S$. catharma but the forewing of $S$. sesops is browner, the top part of the tegumen is short, broad, and the cucullus is broad and much shorter.

\section{Description}

Wingspan $7.5 \mathrm{~mm}$. Head and thorax brownish. Forewing ground colour brownish; costal strigulae paler, indistinct; divisions brown; strigulation weak, brown. Markings reduced to postbasal fascia extending in dorsal half of wing and subterminal fascia accompanied by weak marking along mid-termen. Cilia brownish. Hindwing brownish, paler in basal third; cilia brownish.

Male genitalia (Fig. 5). Terminal projection of tegumen short, broad; basal third of valva broader than cucullus; neck fairly broad; cucullus weakly tapering terminally; aedeagus short, broad basally, tapering ventro-terminally.

Female genitalia (Fig. 13). Sterigma broad, rounded proximally, slightly protruding in middle posteriorly; ostium area large with lateral sclerites; sclerite of antrum rather weak, broad; signum single.

\section{Material}

Holotype male: "Brasil: AL[agoas], Ibateguara 400 m, 10-20, III. 1994, V.O. BECKER Col; Col. BECKER 91074"; GS 615 WZ. Paratypes two identically labelled specimens, female with GS 614 WZ.

\section{Etymology}

The specific name is based on the facies of the moth: Greek: ses - tineid moth (genitive: seos), ops - appearance.

\section{Satronia mantissa sp. $\mathbf{n}$.}

(Figs 6, 18)

\section{Diagnosis}

$S$. mantissa is closely related to $S$. mesaea but has a quite different facies (slender, greyish forewing); the genitalia of the two are similar but in S. mantissa the sacculus angle is smaller, the proximal edge of the ventral incision of the valve is perpendicular to the sacculus, and the aedeagus is shorter. 


\section{Description}

Wingspan ca. $10 \mathrm{~mm}$. Head and thorax pale brownish grey. Forewing slender, not expanding posteriorly. Ground colour whitish grey, in distal third more brownish grey; strigulation and fine lines brownish grey; costal strigulae paler than ground colour; divisions brownish grey. Markings rather concolorous with strigulation: basal blotch small; postbasal fascia reduced to a line; median fascia very slender, preserved at costal third; subterminal fascia curved medially; subapical fascia short, blackish brown; apical field pale. Cilia darker than ground colour. Hindwing whitish, suffused brownish posteriorly; venation pale brownish; cilia pale brownish.

Male genitalia (Fig. 6). Terminal projection of tegumen broad, short; basal third of valva subsquare; neck very short, slender; incision deep; sacculus angulate; cucullus elongate-oval; aedeagus moderately long, slightly tapering terminad.

Female unknown.

\section{Material examined}

Holotype male: "Brasil: S[anta]C[atarina], Sao Joaquim 1400 m, 22-24. I. 1983, V.O. BECKER Col; Col. BECKER 52315”; GS 872 WZ.

\section{Etymology}

The name refers to the large number of the Satronia species; Latin: mantissa - an addition.

\section{Satronia mesaea sp. n.}

(Figs 7, 19)

\section{Diagnosis}

$S$. mesaea is closely related to $S$. mantissa but the distal part of its sacculus is broadly rounded, the straight part of the anterior edge of the basal incision of the valva is short, and the caudal edge of the sacculus is more convex. The moth is large, with an expanding forewing and a rather brownish appearance.

\section{Description}

Wingspan $13 \mathrm{~mm}$. Head and thorax brown; labial palpus paler. Forewing weakly expanding somewhat terminally; costa and termen almost straight. Ground colour pale brownish; strigulation weak, brown; costal strigulae fine, whiter than ground colour; divisions brown. Markings brown, ill-defined: dorsal traces of postbasal and median fascia; subterminal facia pale marked by a row of blackish dots; subapical fascia connected with terminal fascia, brown. Cilia brownish. Hindwing brownish with brown venation; veins Sc-M1 anastomosing; 
cilia slightly paler than wing.

Male genitalia (Fig. 7). Top part of tegumen broad; basal part of valva broad; ventral incision deep; neck slender; sacculus broadly rounded posteriorly; cucullus broad; aedeagus moderate.

Female unknown.

\section{Material examined}

Holotype male: "Brasil: GO[ias], Paraiso 1300 m, 11. II. 1996, V.O. BECKER Col; Col. BECKER 98343”; GS 944 WZ. Paratype male from same state, Teresina 500 m, 29. V. 1992; colln Nr. 92639; GS 943 WZ.

\section{Etymology}

The specific name derives from Greek word mesaios, meaning median, as this species is intermediate between $S$. mantissa and S. lita.

\section{Satronia lita sp. n.}

(Figs 8, 20)

\section{Diagnosis}

S. lita is similar to $S$. mesaea but lita is pale-coloured with an oblique proximal edge of the ventral incision of the valva, and a strong proximal projection of the base of the ventral lobe of the cucullus.

\section{Description}

Wingspan $9 \mathrm{~mm}$. Head and thorax white-grey, labial palpus slightly tinged brown. Forewing weakly expanding somewhat terminal. Ground colour whitish; suffusions and strigulation grey; costal strigulae fine, whitish; divisions grey. Markings grey: basal blotch small, indistinct; postbasal fascia interrupted subcostally and subdorsally; median fascia rudimentary; subterminal fascia atrophying towards costa; terminal fascia and apical spots distinct. Cilia whitish grey. Hindwing whitish grey tinged brownish on periphery with brownish venation and paler cilia.

Male genitalia (Fig. 8). Apical lobe of tegumen distinct, rounded; basal half of valva broad; sacculus rounded posteriorly with a slender lobe of proximal edge of ventral incision of valva; neck short, slender; cucullus broad, oval with well-developed projection of ventral lobe; aedeagus broad proximally; cornuti strong with short lateral projections.

Female unknown. 


\section{Material examined}

Holotype male: "Costa Rica Turrialba 600 m, VIII. 1981, V.O. BECKER Col; Col. BECKER 46044”; GS 986 WZ.

\section{Etymology}

The name refers to the facies of the moth; Greek: litos - simple.

\section{Satronia laepha sp. n.}

(Figs 9, 21)

\section{Diagnosis}

S. laepha might be closely related to $S$. lita as the shapes of the sacculus and aedeagus suggest, but $S$. laepha has some lines in the median area of the forewing and a distinct terminal process on the aedeagus.

\section{Description}

Wingspan $9.5 \mathrm{~mm}$. Head and thorax greyish. Forewing as in S. lita. Ground colour greyish; strigulation and lines brownish grey; costal strigulae whitish grey; divisions grey-brown. Markings reduced to lines representing posterior edges of fascia; subterminal fascia in form of a series of blackish dots; subapical fascia short, blackish concolorous with apical spots. Cilia pale brownish grey. Hindwing whitish brown with darker peripheries and venation; cilia pale brownish.

Male genitalia (Fig. 9). Terminal part of tegumen large; basal half of valva large with slender fold of proximal edge of basal incision; neck slender, expanding towards cucullus; cucullus subtriangular; aedeagus fairly large, tapering terminad with latero-posterior process.

Female unknown.

\section{Material examined}

Holotype male: "Brasil: S[anta]C[atarina], Brusque 100 m, 15-20. I. 1983, V.O. BECKER Col; Col. BECKER 51894"; GS 847 WZ.

\section{Etymology}

The specific epithet concerns the facies of the moth; Greek: laiphos - a poor, dirty robe. 


\section{Satronia sinuata sp. n.}

(Figs 10, 22)

\section{Diagnosis}

$S$. sinuata is closely related to $S$. laepha but $S$. sinuata has a uniformly brownish hindwing and a slender spine-like process from the latero-postmedian part of the aedeagus.

\section{Description}

Wingspan $10 \mathrm{~mm}$. Head and thorax brownish grey, labial palpus paler. Forewing typical of the genus. Ground colour white-grey in distal part of wing suffused grey with small rusty parts; strigulation and lines brownish grey. Markings brownish grey with darker edges consisting of basal blotch, remnants of median fascia; subterminal and subapical fascia dark grey with blackish strigulae and spots; terminal fascia not complete. Cilia brown-grey. Hindwing brownish; cilia paler.

Male genitalia (Fig. 10). Apical part of tegumen short, broad; basal half of valva subsquare; ventral edge of sacculus almost straight; proximal edge of ventral incision of valva straight; neck short, slender; ventral lobe of cucullus broadly convex proximally; aedeagus broad with slender (somewhat variable in size) spine-like process.

Female unknown.

\section{Material examined}

Holotype male: "Brasil: D[istrito]F[ederal], Planaltina 1000 m, 25. XI. 1985, V.O. BECKER Col; Col. BECKER 58062"; GS 892 WZ. Paratypes three identically labelled males, and one male from Minas Gerais (Sete Lagoas 720 m, 20. X. 1969, colln Nr. 6099; GS 1335 WZ).

\section{Etymology}

The specific name refers to the shape of sacculus; Latin: sinuata - sinuate.

\section{Satronia pheidologeton sp. $\mathrm{n}$.}

(Figs 11, 23)

\section{Diagnosis}

S. pheidologeton is closely related to $S$. sinuata but has the forewing ground colour whitish, the subterminal fascia is broad and dark, and there is a dorsal thorn at the end of the aedeagus. 


\section{Description}

Wingspan $8 \mathrm{~mm}$. Head and thorax greyish white. Forewing slender; ground colour whitish tinged grey along costa; strigulation grey; costal strigulae whitish; divisions grey-brown. Markings ill-defined, brownish grey in form of basal blotch and median fascia reduced to suffusions at wing edges; subterminal fascia broad, brown with black marks; subapical fascia absent. Cilia greyish, whitish at tornus. Hindwing pale brownish white, paler basally; cilia paler.

Male genitalia (Fig. 11). Terminal part of tegumen short with short apical portion; basal half of valva broad; neck slender, straight; sacculus straight ventrally, angulately rounded posteriorly; cucullus fairly large with proximal edge of ventral lobe extending; aedeagus large with strong terminal spines.

Female unknown.

\section{Material examined}

Holotype male: "Brasil: R[io de]J[aneiro], Marica 5 m, 12-15. I. 1989, V.O. BECKER Col; Col BECKER 54624"; GS 883 WZ. Paratype an identically labelled male.

\section{Etymology}

The specific epithet refers to the relation with the former species; Greek: pheidos - poor and getion (latinized: geton) - a neighbour.

\section{REFERENCES}

ADAMSKI D., BRown J.W. 2001. Systematic revision of the Ecdytolopha group of genera (Lepidoptera: Tortricidae: Grapholitini) in the New World. Entomologica Scandinavica Supplement 58: 1-86.

BROWN J.W., BAIXERAS J. 2006. Macrocydia divergens, a new genus and species of Grapholitini (Lepidoptera: Tortricidae: Olethreutinae) from Central America. Zootaxa 1197: 45-54.

HEINRICH C. 1926. Revision of the North American moths of the subfamilies Laspeyresiinae and Olethreutinae. Bulletin of the United States National Museum 132: 1-216, 76 pls.

Powell J.A. RAzowski, J., Brown, J.W., Brown, R.L., 1995. Tortricidae. [in:] J.B. HePPNER (ed.). Atlas of Neotropical Lepidoptera, Checklist: Part 2. Hyblaeoidea - Pyraloidea - Tortricoidea. Association of Tropical Lepidoptera, Gainesville, 138-157.

RAZOWSKI J. 2011. New species, new genera, and new combinations of Grapholitini (Lepidoptera: Tortricidae) from the Neotropical Region. Acta Zoologica Cracoviensia 53A(1-2): 37-101.

RAZOWSKI J., BECKER V.O. 2011. Systematics and faunistics of Grapholitini,1: Ricula HeINRICH and its allies (Lepidoptera: Tortricidae). Acta Zoologica Cracoviensia 54(1-2): 129-168.

RAZOWSKI J., BECKER V.O. 2012a. Systematics and faunistics of Grapholitini, 2: Ethelgoda HeINRICH, Ofatulena HeInRICH, Cyanocydia gen. n., and Metacydia gen. n. Polish Journal of Entomology 81(3): 
195-206.

RAZOWSKI J., BeCKER V.O. 2012b. Systematics and faunistics of Grapholitini,4: Dichrorampha GuENÉE, 1845 (Lepidoptera: Tortricidae). SHILAP Revista de Lepidopterología 40(158): 207-222.

RAZOwSKi J., BeCKER V.O. 2013a. Systematics and faunistics of Grapholitini, 5: Phloerampha, Goditha and Ranapoaca (Lepidoptera: Tortricidae). Polish Journal of Entomology 82(3): 175-186.

RAZOWSKI J., BECKER V.O. 2013b. Systematics and faunistics of Grapholitini, 6: Grapholita TREITSCHKE, Eriosocia RAZOWSKI \& BROWN and Coniostola DiAKONOFF. Polish Journal of Entomology 82(3): 187-199.

RAzOWSKI J., BECKER V.O. 2014. Systematics and faunistics of the Neotropical Grapholitini, 4: Cydia HÜBNER, [1825] (Lepidoptera: Tortricidae). SHILAP Revista de Lepidopterología 42(168): 545-557.

RAzOWSKI J., BROWn J.W. 2008. A new genus for Laspeyresia guttifera MEYRICK (Lepidoptera: Tortricidae: Olethreutinae) from the northern Neotropics. Proceedings of the Entomological Society of Washington 110(3): 635-642.

Received: 7 July 2015

Accepted: 1 September 2015 